DEMOGRAPHIC RESEARCH

VOLUME 33, ARTICLE 9, PAGES 239-272

PUBLISHED 22 JULY 2015

http://www.demographic-research.org/Volumes/Vol33/9/

DOI: 10.4054/DemRes.2015.33.9

Research Article

The low importance of marriage in eastern

Germany - social norms and the role of peoples' perceptions of the past

\title{
Andreas Klärner
}

This publication is part of the Special Collection on "Focus on Partnerships: Discourses on cohabitation and marriage throughout Europe and Australia," organized by Guest Editors Brienna Perelli-Harris and Laura Bernardi.

(c) 2015 Andreas Klärner.

This open-access work is published under the terms of the Creative Commons Attribution NonCommercial License 2.0 Germany, which permits use, reproduction \& distribution in any medium for non-commercial purposes, provided the original author(s) and source are given credit.

See http:// creativecommons.org/licenses/by-nc/2.0/de/ 


\section{Table of Contents}

$\begin{array}{lll}1 & \text { Introduction } & 240\end{array}$

2 Theoretical background 241

3 The Eastern German context 244

$4 \quad$ Methods 246

4.1 Background: The city of Rostock in context 247

4.2 The sample 248

4.3 The focus group interviews 249

$\begin{array}{lll}4.4 & \text { Data analysis } & 250\end{array}$

$5 \quad$ Results 250

$5.1 \quad$ Low desire for marriage 251

5.2 Reasons against marriage: Uncertainty and individualization 252

$5.3 \quad$ Motives for marrying 254

5.4 Relating to the GDR past - the changing role of the state 257

$6 \quad$ Summary and discussion 259

$7 \quad$ Acknowledgements 263

References 264 


\title{
The low importance of marriage in eastern Germany - social norms and the role of peoples' perceptions of the past
}

\author{
Andreas Klärner ${ }^{1}$
}

\begin{abstract}
BACKGROUND

Eastern Germany is a region with one of the world's highest percentages of non-marital births. Marriage and childbearing seem to be decoupled. This brings into question people's views on the institution of marriage.
\end{abstract}

\section{OBJECTIVE}

This paper examines eastern Germans' views on cohabitation, marriage, and childbearing. It argues that historical, social, and political contexts shape the social norms of marriage and non-marital childbearing.

\section{METHODS}

This paper presents data from eight qualitative focus group interviews with 74 women and men aged 25-40 in Rostock, a medium-sized city in eastern Germany.

\section{RESULTS}

The respondents often compared their own motives and incentives for marriage with those which existed in the socialist German Democratic Republic (GDR) and held true for their parents. Many of them stated that having children was important for them as individuals and for their partnership. However, they treated the decision to get married and the decision to have children as two separate issues. Respondents often referred to the past and said that the strong legal and financial incentives to marry in the past regime in the socialist GDR no longer exist. Today's incentives were seen as minor, or as irrelevant to their personal situations.

\footnotetext{
${ }^{1}$ Faculty of Economic and Social Sciences, Institute of Sociology and Demographic Research, University of Rostock. E-Mail: andreas.klaerner@uni-rostock.de.
} 


\section{Introduction}

In almost all European countries, marriage rates have been declining since the 1960s and the share of non-marital births has been rising for several decades (Perelli-Harris et al. 2010, 2012). This coincides with alternative partnership and living arrangements such as long-term cohabitation, single parenthood, childless marriages, living apart together, 'patchwork' families, and living alone becoming much more widespread (Sobotka and Toulemon 2008). In general, research in western, industrialized countries has shown that traditional marriage has become one option among many, and people are more often choosing other ways of pursuing their life goals (Beck-Gernsheim 1998, 2002). Research also shows that longer phases of cohabitation are preceding or even substituting for marriage. Faced with multiple choices of lifestyle and living arrangement -, with or without a partner, with or without children - individual actors have to actively choose marriage over cohabitation (Thornton, Axinn, and Xie 2007). Many researchers have concluded that marriage can no longer be regarded as a selfevident and unquestioned institution, and that marriage "has become less influential in delineating the relationships between men and women, the transition to adulthood, and the identity for men and women", and it "has also become less relevant as a context for sexual expression, living arrangements, and the bearing and rearing of children" (ibid.: 4).

Eastern Germany, which was formerly the socialist state of the German Democratic Republic, is a special case of partnership change where the decoupling of marriage and childbearing is very advanced. Eastern Germany has one of the world's highest percentages of non-marital births: in 2012 over 60\% of births in eastern Germany were non-marital (see Section 3, and Nazio and Blossfeld 2003; Konietzka and Kreyenfeld 2002; Klüsener and Kreyenfeld 2009; Klüsener, Perelli-Harris, and Sánchez Gassen 2013; Kreyenfeld and Konietzka 2008). This extraordinarily high proportion of non-marital births is the reason why this region deserves a closer look.

In the following, I will argue that common theoretical explanations for these trends that mainly focus on policies, laws, economics, and broader cultural changes such as value change need to be complemented with an agency approach that embeds individuals in a personal, social, and cultural context (see Section 2). This approach stresses that individuals' actions and decisions are framed by specific social norms. In accordance with the life course perspective, I also want to stress that actors' lives and decisions are interlinked with other peoples' lives: individuals' decisions about partnership formation, marriage, and cohabitation are influenced by the past and present experiences of their parents and significant others. This social, personal, and normative context of agency influences the meaning and decision-making of individual actors. 
Hence, I want to address the following questions in the case of eastern Germany: 1) what meanings do women and men in eastern Germany currently attach to marriage? 2) how are these meanings influenced by social norms and regional and cultural historical traditions? Addressing these questions will provide insight into how historical, social, and political context shape the social norms of marriage and nonmarital childbearing that are relevant to individuals' decisions on marriage and alternative partnership arrangements.

One way of studying social norms and the formation of meaning is the qualitative method of focus groups (see Section 4). In my paper I will present results from focus groups with 74 women and men aged 25-40, interviewed in Rostock, a city in the northern part of eastern Germany (see Section 4.1). The focus groups were conducted to elicit general social norms about marriage, cohabitation, and childbearing in order to explore the meaning of marriage in the eastern German context.

My results show that the focus group respondents often compared their own motives and incentives for marriage with those that existed in the socialist German Democratic Republic (GDR) and held true for their parents. Many of them stated that having children was important for them as individuals and for their partnership. However, they treated the decision to get married and the decision to have children as two separate issues. The respondents often referred to the past, and said that the strong legal and financial incentives for marriage in the old socialist regime in the GDR no longer exist. Today's incentives were seen as minor, or as irrelevant to their personal situations.

\section{Theoretical background}

Common theoretical explanations of the decline in marriage and increase in non-marital births in western industrialized countries often focus on: 1) the effect of welfare states and family laws and policies; 2) the effect of economic uncertainty on the timing and postponement of marriage; and 3) changes in historic and current cultural values, often referred to as the theory of the Second Demographic Transition (e.g., van de Kaa 1987, 2001; Lesthaeghe 2010). I will draw on these theories, but I want to stress that they often neglect regional cultural traditions and specific social norms that influence individual actors' decision-making. Thus, I want to complement these theories by taking an agency approach that embeds individuals in a social and historical context.

Over the past century, welfare-state support for parents and children (e.g., child benefits and public childcare) and social security measures (e.g., unemployment benefits and welfare aid) have reduced individuals' dependence on the labor market and family support (Esping Andersen 1990, 1999). Women benefitted from these changes 
and gained more individual freedom, so that they no longer had to rely on a husband's income. Klüsener, Perelli-Harris, and Sanchez Gassen (2013: 142) argue that "[t]hese state institutions may have allowed women to become less reliant on the institution of marriage and instead more willing to have children outside of marriage.” In effect, these policies not only strengthened legal acceptance of non-marital childbearing and cohabitation by largely eliminating legal discrimination of non-marital unions and nonmarital births (McDonald 2006; Perelli-Harris and Sánchez Gassen 2012; Klüsener, Perelli-Harris, and Sánchez Gassen 2013) but also reflected and promoted social acceptance of new family forms such as cohabitation and single parenting (Axinn and Thornton 2000; Barlow 2004; Barlow and Probert 2004; Beck-Gernsheim 2012; Bowman 2010; Levin 2004; Nazio and Blossfeld 2003). However, it is unclear if the policies changed union formation behavior or if they were a response to changes in union formation.

Economic uncertainty about future employment and declining wages are also key factors in explaining changes in demographic behavior in general and non-marital fertility in particular (cf. Bastin, Kreyenfeld, and Schnor 2013; Sobotka, Skirbekk, and Philipov 2011, Perelli-Harris et al 2010). Rapid economic change, new labor markets, and the diminishing power of states to provide social security have led to an increase in individual feelings of uncertainty (Bauman 2007). Economic uncertainty especially influences those with less education and couples from the lower social strata (PerelliHarris et al. 2010). For women with less education, motherhood may be a choice to reduce uncertainty and give structure to their lives (Friedman, Hechter, and Kanazawa 1994; Graham and McDermott 2006), whereas their male partners might not have the financial means to provide for mother and child and to turn the relationship into marriage (Gibson-Davis, Edin, and McLanahan 2005; Kravdal 1999; Mills and Blossfeld 2003; Oppenheimer 2003; Oppenheimer, Kalmijn, and Lim 1997; Sobotka and Toulemon 2008; Perelli-Harris et al. 2010). Hence, those facing economic uncertainty may be more likely to cohabit and less likely to marry.

Finally, "value change" (Inglehart 1977), usually connected with the theory of the Second Demographic Transition (van de Kaa 1987), may be facilitating increased cohabitation and non-marital fertility. According to this approach, the post-modern, individualistic values of self-realization, which began to emerge in western countries in the 1960s as a result of economic prosperity, compete with the binding aspects of marriage (Billari, Liefbroer, and Philipov 2006; Lesthaeghe 2010; Surkyn and Lesthaeghe 2004; van de Kaa 1987, 2001). Traditional ways of sequencing life course events, such as first marrying and then having children, became one option among many, and people began to choose different ways of pursuing their life goals. In effect, getting married and having children became less self-evident and were no longer default options: instead, they now had to be actively chosen (Beck-Gernsheim 2002). 
All of these theories contribute to our overall understanding of the long-term trend of increasing levels of cohabitation and non-marital childbearing, either by focusing on the effects of the economy, law, and politics or by exploring cross-national, generalized trends of the diffusion of 'postmodern values' in the western world. What they often neglect is the importance of regional and national cultures and traditions in understanding why these trends are happening at different speeds and with different amplitudes in distinct countries (Kalmijn 2007; Klüsener, Perelli-Harris, and Sánchez Gassen 2013; Manting 1996; Sobotka and Toulemon 2008). Further, and even more importantly, these theories often relate to the concept of social norms and argue that change or liberalization of social norms around sexual behavior and intimate relationships causes the diffusion of cohabitation and non-marital births (Ramsøy 1994; Thornton and Philipov 2009; Lesthaeghe 2010). However, previous research has rarely focused on the actual processes of social interaction and meaning-making in which individuals reproduce and modify these social norms (e.g., Mynarska and Bernardi 2007).

I argue that the aforementioned theoretical explanations need a complementary approach that focuses on individual agency and social norms. From an agency point of view (e.g., Granovetter 1985; Coleman 1986), changing marriage rates and the increase in the share of non-marital births are the result of individual actions and decisions that are influenced but not fully determined by social structures. On the one hand, people adapt to different legislation, react to changes in civil law, take advantage of policy changes, and respond to economic conditions. But, on the other hand, people's choices are not completely determined by policies, laws, and economics. Values and behaviors can develop and change irrespective of a given legal framework, sometimes making it necessary to adapt legislation to changing beliefs, convictions, attitudes, demands, and behaviors. People are to some extent free to interpret situations, find their own way of dealing with economic trends, and sometimes even act irrationally. An agency point of view also stresses that individual actors do not act in isolation but rather are embedded in a personal, social, and historical context. Their actions are based on beliefs and ideals formed within this context, informed by the past and oriented towards the future (Emirbayer and Mische 1998).

Taking a life course perspective, actors' lives and decisions are also interlinked with other peoples' lives. Life course transitions are influenced by past and present experiences of parents and other 'significant others', and the sequencing of life course events is a dynamic process of different educational, vocational, and familial pathways (Bengtson and Allen 1993; Elder 1985; Mayer 2009). People construct their social reality according to their own beliefs and ideals, but also in accordance (or in conflict) with general social norms and beliefs. Consequently, their demographic behaviors (e.g., getting married, having children) are at least partly dependent on their social 
perceptions and constructions of reality. Thus, it is important to examine peoples' motives both for marrying and for not marrying, and it is crucial to question how these motives are socially and institutionally formed.

\section{The Eastern German context}

Eastern Germany is a special case, because the territory of eastern Germany, or the 'neue Bundesländer' (new federal states), was the sovereign, socialist state of the German Democratic Republic (GDR) until 1990, after which, like other European socialist countries, it transformed from a socialist to a market economy. However, the GDR is the only post-socialist country that was then directly united with another sovereign state, the Federal Republic of Germany (FRG). The existing political and economic structure of the FRG was superimposed on the territory of the GDR on October 3, 1990. Rather than having a gradual phase of transition, there was a sudden change. In that respect, eastern Germany is often seen as a 'natural experiment' (Witte and Wagner 1995: 387; Mayer and Solga 2010: 39) for social sciences, in which the impact of policies and economic conditions on individual agency on the one hand, and the importance of cultural traditions and the persistence of cognitive structures or habitus to peoples' modes of action on the other hand, can be disentangled and studied. This is especially true for all aspects concerning family relationships, such as fertility and marriage patterns, as well as couple and gender relationships, simply because the FRG and the GDR were characterized by different and contrary family regimes, gender relations, and state policies towards marriage and fertility (see Engelhardt, Trappe, and Dronkers 2002; Huinink, Kreyenfeld, and Trappe 2012; Krause and Ostner 2010; PfauEffinger and Geissler 2002; Pfau-Effinger and Smidt 2011; Salles 2006; Trappe 1995). While family policies in the FRG focused on protecting a very conservative conception of the family in which the male breadwinner model prevailed, family policies in the GDR focused on integrating women into the labor force and provided incentives for early marriage and childbearing, as well as special support for single mothers (Huinink and Wagner 1995; Rosenfeld, Trappe, and Gornick 2004). Because women and mothers in the GDR were part of the labor force, worked full-time, and were financially independent, single parenthood and divorce were less risky than in the FRG.

After unification, FRG marriage and family law was adopted by the whole of Germany (Pfau-Effinger and Geissler 2002). As a result, many of the financial incentives for (early) marriage and childbearing were eliminated. Yet marriage still has some privileges (spouses' right to refuse to give evidence, inheritance, right to information in case of accidents etc.) and is protected by constitutional law. However, financial support is limited and/or dependent on having children; e.g., child allowance 
is granted regardless of being married. Tax laws privilege married couples through the joint taxation of husbands' and wife's earnings, but that only pays off when one spouse earns considerably less money than the other. Another marriage privilege is paternity law. According to German law, only married fathers are legally recognized as the father upon birth of a child. Unmarried fathers have to officially acknowledge fatherhood to a state representative and the mother of the child has to consent.

The high level of non-marital fertility in eastern Germany can be seen in Figure 1, which displays the extraordinarily high share of non-marital births relative to the German and European contexts. In eastern Germany 61.6\% of all births in 2012 were non-marital; in Rostock, the city in eastern Germany where the focus group data for this paper were collected, the share was even higher, at $63.5 \%$. It is typical that an urban area such as Rostock, where individualization and modernization processes are more advanced than in rural areas, has a slightly higher share of non-marital births than eastern Germany in total. In western Germany the share was much lower, at 28.4\%, which is also below the $39.1 \%$ (data from 2011) in the Euro area. The graph for eastern Germany also shows that the figures surged in the mid-1970s when financial benefits for lone mothers were introduced, but did not drop after this when benefits were extended to all mothers. They also continued to rise after unification when a couple of marriage benefits were abandoned.

Taking a life course perspective and looking at the prevalence of partnership arrangements in unified Germany, research finds that cohabitation is widespread in eastern Germany, but this partnership arrangement only infrequently leads to marriage (Kreyenfeld and Konietzka 2010). This holds true even when cohabiting couples become parents. For the eastern and western German female birth cohorts of 1971-73, Bastin, Kreyenfeld, and Schnor (2013) show that the majority of eastern German mothers are not married upon birth of their first child, and they are also less likely than western German women to marry after this event. Bastin, Kreyenfeld, and Schnor (2013) also show that while marriages in eastern Germany are less stable than those in western Germany, the separation risk of cohabiting couples is lower in eastern than in western Germany. They argue that cohabitation with and without children can be regarded as a stable and durable partnership arrangement, and that there is a decoupling of marriage and family formation in eastern Germany. Researchers mention low religiosity and women's higher vocational aspirations as well as a generally lower level of life satisfaction as causes of the lower marriage disposition in eastern Germany (Arranz-Becker, Lois, and Nauck 2010; Schnor 2012). 


\section{Figure 1: Share of non-marital births in selected regions}

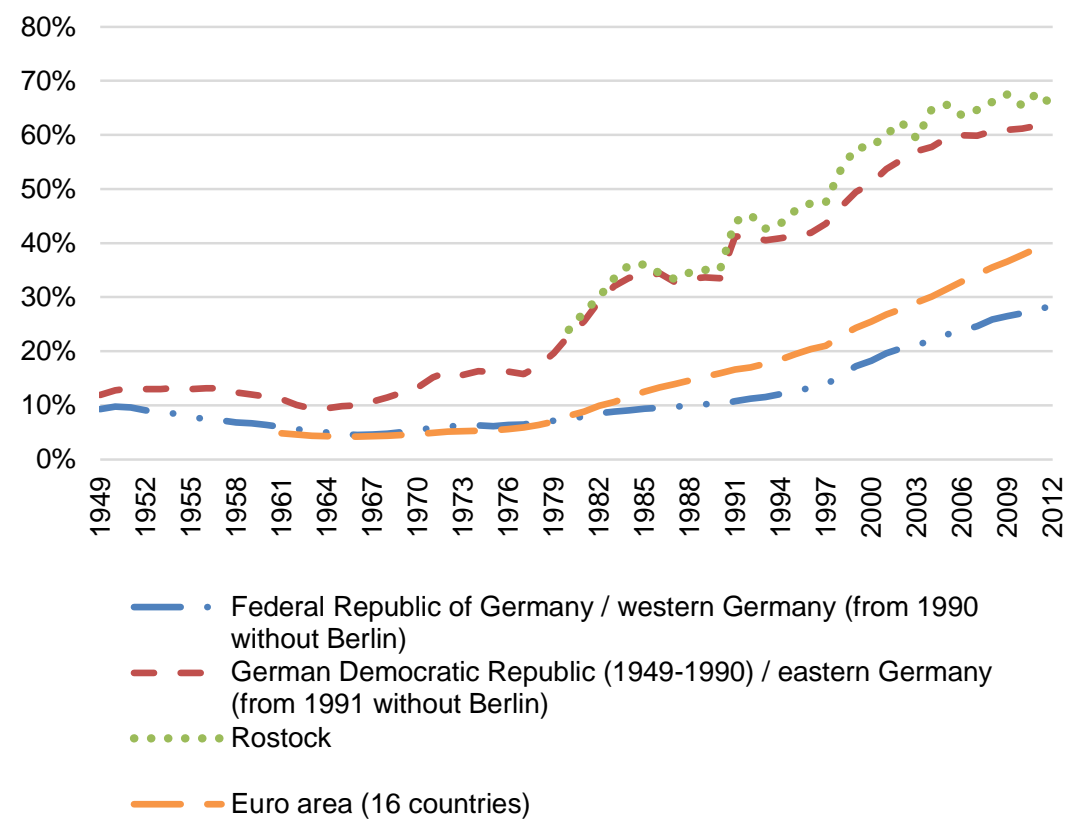

Data Source: Statistisches Bundesamt, Statistisches Landesamt Mecklenburg-Vorpommern, EUROSTAT; own calculation and illustration.

Survey data show that the majority of eastern German respondents aged 18 to 45 do not regard marriage as necessary or desirable in the case of a couple living together for a long time or when there is a child born in the partnership (Peuckert 2012: 43). Survey data also shows that full time employment of mothers is socially accepted in eastern Germany and is not perceived as 'harmful' to the child (Träger 2009). Few studies, however, address the values or meanings of marriage in eastern Germany using qualitative data.

\section{Methods}

The focus groups carried out in Rostock are part of a larger project (Perelli-Harris et al. 2014). The project is designed to explain different patterns of family formation and partnership arrangement in European countries and to address different social norms of 
non-traditional family arrangements such as cohabitation and non-marital childbearing. One way of eliciting people's beliefs about these norms is through the use of qualitative focus group discussions (Barbour 2007; Bloor et al. 2001; Liamputtong 2011; Patton 2002; Stewart, Shamdasani, and Rook 2007).

Focus group discussions are usually conducted with groups of six to ten people who are invited to discuss a specific topic, in our case that of marriage, cohabitation, and childbearing. In contrast to qualitative interviews, which are done with single individuals and focus on their subjective theories, sense-making, action strategies, ways of coping, and so on, focus group discussions use the dynamic of group interaction and conversation "as the central source of knowledge" (Flick 2009: 196). The focus group technique tries to study how attitudes, opinions, and social norms are produced in social interactions by placing a group of people in a setting that resembles 'normal', everyday interactions more and better than the artificial situation of an interview with a single individual. By discussing a specific topic and giving each of the participants of the group discussion the opportunity to express their opinion, social norms usually emerge while discussing these opinions. Some of the opinions are shared and unquestioned by the group, while other opinions are sanctioned (by objections, disapproval, ridicule etc.). By analyzing these interactions the objective is "to better understand the group dynamics that affect individuals' perceptions, information processing, and decisionmaking” (Stewart, Shamdasani, and Rook 2007: 9), i.e., the social norms that influence individuals' thinking and acting.

\subsection{Background: The city of Rostock in context}

We conducted eight qualitative interviews with focus groups in Rostock, eastern Germany, in spring 2012. Rostock is situated on the Baltic coast in the north-eastern part of Germany and is a medium-sized city of around 200,000 inhabitants, and the biggest city of the federal state of Mecklenburg-Vorpommern (M-V), which has approximately 1.6 million inhabitants. $\mathrm{M}-\mathrm{V}$ is a sparsely populated region of Germany, with agriculture, fishery, shipbuilding, and tourism as the main industries. The shipyard industry in $\mathrm{M}-\mathrm{V}$ was severely hit by the economic collapse of the GDR, but it is slowly recovering and new industries such as wind energy and cruise ship tourism are emerging. Since 1990 unemployment has been nearly twice as high as Germany's mean unemployment rate. Germany's highest mean unemployment rate was 20.4\% in 2004 (Rostock: $19.9 \%{ }^{2}$, Germany: 10.5\%) and in 2012 when the focus groups were conducted it was $12 \%$ (Rostock: $12.1 \%$, Germany $6.8 \%$ ). Rostock, like almost any

\footnotetext{
2 This figure is for 2005, as there is no comparable data for 2004. The trend since 1990 shows that unemployment rates in Rostock and $\mathrm{M}-\mathrm{V}$ vary, with Rostock scoring around 0.3 lower than $\mathrm{M}-\mathrm{V}$.
} 
other eastern German city or region, lost many inhabitants who moved to western Germany after the opening of the wall in 1989/90. But the figure is stabilizing and even slowly growing again. Rostock has a university with a medical clinic. The university has around 15,000 students and is the biggest employer in the city (5,000 employees).

As a result of the "forced secularization"3 (Wohlrab-Sahr, Karstein, and SchmidtLux 2009) of the GDR regime, eastern Germany is one of the regions in the world with the highest share of people unaffiliated with any religion (Froese and Pfaff 2005; Pickel 2012). Census data from 2011 show that around $75 \%$ of the eastern German population belong to neither the Protestant nor the Catholic Church (other religions are negligible; see Statistische Ämter des Bundes und der Länder 2014). The minor role of religion in eastern Germany is often seen as one factor liberalizing social norms towards nonmarital births (Arranz-Becker, Lois, and Nauck 2010; Meulemann 2003; Pickel 2012).

While Rostock stands out as an urban environment in a federal state dominated by rural regions and with an agricultural base, the presented data do not indicate that Rostock stands out in respect to population dynamics (especially out-migration), labor market, or any other socio-demographic indicator. Unemployment and out-migration are problems that are typical of eastern Germany. Taking all this into account, Rostock can be regarded as largely typical of eastern Germany.

\subsection{The sample}

Participants were recruited by a local market research institute which approached people on the streets and via telephone. We recruited participants between the ages of 25 and 40 . The older age groups reached the family formation age shortly after the fall of the socialist regime and witnessed the changes in the economic and cultural system (Keller and Marten 2012; Mayer and Schulze 2009), whereas the younger respondents could not remember the GDR but their parents, who had been fully socialized under the socialist regime, passed on their experiences, values, and norms to the younger generation, i.e., our respondents. Therefore these respondents would be well aware of differences and conflicts between their parents' views, shaped by the GDR, and their own views on life, shaped in a unified Germany.

We invited 10 participants to each of the 8 focus groups. The response rate was very high: in 5 groups all 10 participants showed up, one group consisted of 9 participants, another group of 8 , and the smallest group had 7 participants. This last group comprised males with lower education, a subpopulation generally known to be

\footnotetext{
${ }^{3}$ The system of the GDR was decidedly anti-religious and impeded religious activities. Churches were not supported by the state and religious activities could have a negative impact on educational and vocational careers.
} 
hard to motivate to participate in social research. Yet even their turn out was good. In sum, 74 men and women from the urban area of Rostock and the neighboring suburban and rural areas attended the sessions. The individual groups were homogeneous with regard to sex and educational level but not with respect to age, marital status, and parity. We divided educational level along the line of the Abitur, a secondary educational degree reached after 12 or 13 years of school attendance. The composition of our sample is displayed in Table 1.

Table 1: $\quad$ Sample composition

\begin{tabular}{|c|c|c|c|c|c|c|c|c|c|c|}
\hline \multirow[b]{2}{*}{ sex } & \multirow[b]{2}{*}{ education } & \multirow[b]{2}{*}{$\boldsymbol{\Sigma}$} & \multicolumn{3}{|c|}{ family status } & \multicolumn{2}{|c|}{ parental status } & \multicolumn{3}{|c|}{ age } \\
\hline & & & $\begin{array}{c}\text { in } \\
\text { partner- } \\
\text { ship }\end{array}$ & married & single & $\begin{array}{c}\text { with } \\
\text { children }\end{array}$ & childless & $25-29$ & $30-34$ & $35-40$ \\
\hline \multirow[t]{2}{*}{ Male } & with Abitur & 19 & 13 & 0 & 6 & 4 & 15 & 11 & - & 8 \\
\hline & $\begin{array}{l}\text { without } \\
\text { Abitur }\end{array}$ & 15 & 6 & 5 & 4 & 7 & 8 & 3 & 4 & 8 \\
\hline \multirow[t]{3}{*}{ Female } & with Abitur & 20 & 10 & 3 & 7 & 6 & 14 & 8 & 3 & 9 \\
\hline & $\begin{array}{l}\text { without } \\
\text { Abitur }\end{array}$ & 20 & 6 & 7 & 7 & 11 & 9 & 9 & 7 & 4 \\
\hline & $\Sigma$ & 74 & 35 & 15 & 24 & 28 & 46 & 31 & 14 & 29 \\
\hline
\end{tabular}

\subsection{The focus group interviews}

The groups were interviewed in a conference room at the Max Planck Institute of Demographic Research in Rostock in the early evening. All of the interviews were led by the author of this article, who was also the principal researcher. The group discussions followed the guidelines developed by the Focus on Partnerships team and covered topics such as the disadvantages and advantages of living together without being married, the motivations for and the barriers to getting married, and the policies and laws relating to cohabitation and marriage (Perelli-Harris et al. 2014). At the beginning the participants were asked to briefly introduce themselves and their personal situations, giving details about where they lived (city, town, rural area), their occupation, marital or partnership status, and whether they had children or not. Subsequently, the moderator gave a brief sketch of how family life and ways of life have changed in recent decades and why the project was relevant and important. Following this, the participants were asked their opinions on these changes and whether they could provide reasons for them. In most focus groups the first response to this 
question was somewhat reluctant, but usually after a few minutes the initial reticence subsided and a lively discussion began. After the interview participants were paid an incentive of $25 €$. The interview sessions were between 60 and 90 minutes long.

\subsection{Data analysis}

Data were analyzed in an iterative process. Immediately following the focus group interview the research team met to de-brief, summarize the contents of the group interview, and discuss the peculiarities of each group. Each member of the research team also took field notes after the focus groups. The recordings of the focus groups were transcribed verbatim. These transcripts were coded using the software package MaxQDA. We applied a two-fold coding strategy using both a bottom-up coding procedure starting with open, in-vivo codes that then were summarized into broader categories, and a thematic coding procedure, coding text excerpts relating to relevant categories such as individualization, economic uncertainty, and GDR times. These codes later helped in retrieving text excerpts, which were then analyzed within the context of the focus group discussion.

The team wrote short portraits of each respondent, summarizing biographical information and the content of their contribution to the group discussion. Everyone involved in the data analysis had helped to conduct the focus groups, and native German speakers carried out the data analysis. The coding procedure was done completely in German, with codes and quotations translated for this article. All translations were discussed with native English speakers from the Focus on Partnership team, and an independent language check was subsequently performed by a bilingual consultant who was not involved in the research project.

\section{Results}

In the following section I present the results of the focus groups showing that 1) there is very little desire for marriage among the participants, 2) uncertainty and individualization hinder people from getting married, 3) economic and romantic motives for marriage are weak, and 4) focus group participants relate their situation to that of their parents during GDR times and conclude that the institution of marriage has lost its function. 


\subsection{Low desire for marriage}

Overall, most respondents in our eastern German focus groups expressed little desire to marry and many participants openly stated that they did not necessarily want to marry, even if they were in a relationship that was intended to last for a long time. Answering the interviewer's questions on reasons for marriage, one unmarried female respondent in a stable relationship said: "There aren't any. I talk to my partner the same way about my problems. We are rock-solid together” (29.03., § 190). Such statements were very common in the focus groups and were uncontested by the other participants. Respondents often described marriage as just a formal procedure, a "certificate" or a "paper" that does not change the meaning or the solidity of a couple's relationship.

As a rationale for not marrying, respondents frequently mentioned that nowadays there simply is no need to be married in order to be happy and satisfied. There were clear indications in the focus group discussions that marriage has lost a great deal of significance for individuals and couples. Sometimes cohabitation and marriage were seen as more or less equivalent, so that cohabitation has a "status indistinguishable from marriage", as Heuveline and Timberlake (2004) put it. One woman said: "It is totally usual that you introduce your partner as husband", and she was supported by the group.

In general, the groups were more or less indifferent towards marriage. They regarded it as neither a very special moment for a couple nor as an act necessary to institutionalize the partnership. One explaining factor that respondents mentioned was the high level of non-religiosity in eastern Germany (Froese and Pfaff 2005; Pickel 2012). Most participants in our groups were not affiliated with any religion, and some participants talked about this "missing" factor. One male respondent who was in a stable partnership and whose partner was pregnant did not see any need to marry: marriage was "not at the forefront, it still has that touch of the church... it's still rooted in the church. And because neither of us is religious, this part is missing, too".

But being indifferent towards marriage does not necessarily imply that the respondents argued against binding relationships in general. Participants repeatedly emphasized that they wanted to have stable, long-term partnerships but did not intend to marry. Marriage-like partnerships with equivalent expectations of stability and the commitment of partners substituted for marriage in many cases, as this participant pointed out:

When I've been together with my partner for such a long time, then marriage will not change the partnership itself. I won't feel more connected to him or anything. If I wasn't before, then marriage won' do it either. And if I want to stay together with him and I'm happy with him, then marriage won't put a feather in the cap. (Female, 26, higher education, partnership, no children) 
Having children was often perceived to be more important for a partnership than marriage. Having children binds partners more tightly to each other, creates a sense of purpose in life, and is seen as being important for society as a whole. Most participants had a positive attitude towards (having) children and believed children were more important to a partnership than marriage:

I think children are important... for two people loving each other. It is a proof of love, a stronger proof (...) than marriage (...). (male, 39, lower education, single, without children)

Having children was seen as one possible motivation to marry, but marriage was not seen as imperative once children arrive. Children were only mentioned as one factor among others that (could) increase the willingness to marry. Sometimes these statements were about potential or hypothetical factors influencing the marriage decisions of others, but not of the speaker.

Only in retrospect did some participants who had children reflect that it would have been easier if they had been married before giving birth to their child. Some respondents found the bureaucratic act of acknowledging paternity as "humiliating":

I remember, when I was pregnant, we went to the youth office and made this acknowledgement of paternity. It felt totally humiliating, especially for my partner, that he had to sign that he really is the father. (Female, 34 years, higher education, married, 1 child)

But even anticipating these obstacles did not necessarily drive the group participants to marriage.

\subsection{Reasons against marriage: Uncertainty and individualization}

When explaining the lack of desire for marriage that was prevalent in the focus groups, we must first analyze the obvious and pronounced reasons for not getting married that emerged from the group discussions. These primarily relate to current economic and social conditions characterized by globalization processes (e.g., liberalization of the labor market) and by the diffusion of postmodern, individualized value orientations such as self-realization, independence, and individual freedom.

As mentioned in Section 2, research on declining fertility and marriage rates links high levels of unemployment, the spread of low-paid and/or time-restricted contracts, and an overall climate of permanent economic crisis to the growing feelings of 
individual uncertainty, which conflict with engaging in long-term commitments such as marriage. But even though eastern Germany, and especially the north-eastern region where our focus groups were held, has high rates of unemployment and our respondents mentioned these conditions, they were not that prominent and were only rarely given as a pronounced reason for not marrying.

Yet feelings of uncertainty in a broader sense emerged regularly in our focus group discussions as an argument against getting married; for example, relating to high divorce rates and often drawing on own or vicarious negative experiences of divorce. Especially the men in the focus groups highlighted the (negative) consequences of marriage. They feared the high cost of marriage and of potential divorce with all its implications, especially financial costs such as legal fees, alimony for the ex-partner, and child maintenance. The latter argument was very prominent among the lowereducated respondents. They mentioned the (potential) financial disadvantages of marriage as an important factor in their reasoning on marriage. They feared both the high cost of a wedding and the negative financial consequences of a possible divorce (attorney fees, maintenance costs/alimony). As one respondent put it, with affirmation from the others:

You shouldn't get married unless you have saved up for a divorce. (Male, lower education, married, 3 children)

But it was not only fear of the financial costs of divorce that was important for our respondents: they also feared the bureaucratic hassles and the emotional strain of getting divorced. Respondents argued that a divorce has to be officially declared and often involves courts and attorneys. Therefore it takes longer than a 'simple' separation and is thus emotionally more stressful. A divorce also involves more potential conflict between partners because property has to be divided.

Economic uncertainty caused by globalization was not a prominent topic in the focus groups, but the broader trends of modernization and individualization were. Eastern Germany is one of the formerly socialist transition countries where modernization and individualization processes have happened in a much shorter time than in western industrialized countries, where such economic, political, and cultural changes had already started in the 1960s (Inglehart 1977, 1997). Respondents frequently remarked on this modernization process and stressed the "new freedoms" the population of the former GDR gained after the revolution of 1989/90. When asked for reasons for the declining marriage rate, one respondent put it this way:

(...)...perhaps this has to do with individualization of the people, that in general everyone has become a bit selfish and wants self-fulfillment and that 
it's harder to compromise. Especially in a marriage, you have to do that. And if you're unattached, you can fulfill yourself, a marriage might be limiting somehow. (Female, 28, higher education, single, no children)

While the term 'selfish' is commonly denoted as pejorative, it must be noted that the focus group participants in general evaluated this trend of individualization as positive rather than negative, due to the new opportunities, freedoms, and selfrealization. However, despite appreciating the new freedoms they have gained in comparison to their parents' generation, some participants pointed out that in their lives family formation, i.e., having children but not necessarily marriage, has only shifted to a higher age, and that it will nevertheless take place.

Among the socio-structural and economic factors that negatively influence marriage plans and marriage behavior, the focus group participants specifically mentioned new career opportunities, especially for women. Our mixed male and female focus groups consistently believed women to be more economically independent of men. Especially the more highly educated women frequently stated that their careers and self-fulfillment come first, and marriage, children, and family planning come second:

We [women, A.K.] are also interested in employment, career, maybe financial independence, we orientate ourselves to this. At least, I do. (Female, higher education, single, no children)

While the women placed more emphasis on the economic aspects of independence, the men in the focus groups stressed the issue of emotional independence and were worried about losing their independence, meaning the freedom to have serial partners. Marriage thus is perceived as an institution of constriction. Men also stressed the loss of spatial mobility/flexibility in connection to job mobility.

\subsection{Motives for marrying}

The prevalent indifference to marriage does not only stem from barriers to marriage or reasons for not getting married. It is also related to the most common motives for getting married, which include economic or functional as well as romantic or symbolic aspects, the arguments for which are weak. Of the economic and functional aspects, the respondents mentioned better protection from layoff or relocation, the right to information in case of accidents/hospitalization, inheritance, and widows' pensions. Yet these legal benefits were believed to be important only in rare cases or to concern 
events that are far in the future, such as the death of a partner, so the respondents did not consider them to be very important at the current time..

One reason for getting married mentioned regularly in the focus groups was the birth of children. Interestingly, this was often discussed as an understandable reason for others but not necessarily for the respondents themselves. It is important to note that children are accepted as a reason for getting married mainly for practical reasons such as child custody (especially for fathers) and child protection:

The thing with the children, I would say, is that today this is the only reason for getting married, if you have children, so that they are taken care of if something happens to someone. Then I would also say that it would actually be better to get married. (Female, 28, higher education)

Yet sharing these attitudes does not necessarily mean that respondents will marry before having a child. In the same group a female respondent who has a child but who is not yet married stated:

For us it's about time we got married, but just for the safety of the child, so that the child is protected. And many things become automatic, if something happened to us. (Female, higher education, 31, relationship, 1 child)

Moral or conventional reasons for getting married when children are present in the partnership were almost unanimously rejected:

I think for children it is not so important [that parents are married]. For many years they don't know what the term 'to marry' is. They have mom and dad, and that's enough for them. (Male, 39, low education, single, no children)

Nor do respondents report any social pressure from the social networks of parents, kin, friends, etc. to get married in the case of parenthood.

Surprisingly, the respondents considered tax benefits, one of the most obvious advantages for married couples, as fairly unimportant in the decision to marry. There might be a social desirability bias in the responses, as marrying for rational financial reasons is frowned upon (socially disapproved). But there is a more obvious explanation: tax benefits for married couples in Germany only apply when one of the partners, traditionally the (house)wife, stays home or receives a considerably lower salary than the husband. Accordingly, especially among the higher-educated respondents, there are few financial benefits from marriage. In particular, if both 
partners have approximately the same salary, there are almost no tax advantages. This means that for most, marriage is not a necessary condition for a satisfying partnership:

“...there aren't economic advantages anymore. I think if there was a tax class in which everyone who was married could save a bundle on taxes, then more people would get married". (Female, 31, higher education, partnership, no children)

This reasoning about lack of tax benefits is typical for eastern Germany, where the gender wage gap is much more narrow than in western Germany (German Federal Statistical Office, n.d.), women's employment rates are much higher, and dual-earner couples form a substantial minority of $41 \%$ of all couple households (Klenner 2009: $622)$.

Of the romantic or symbolic motives for marriage, respondents mentioned "love", a "feeling of security", being a "proper family", "bearing the same name", and making a public statement of commitment to the partner. These beliefs were mainly held by women, who said that romantic motives are the only legitimate reason for marrying: in the male discussion groups the participants thought that these romantic motives might be relevant for women. But overall these motives are of secondary importance, sometimes believed to be important for others but not relevant to the respondents themselves. Respondents advocating these motives often felt the need to defend themselves against the group for having these attitudes. Discussing these motives in one group, a female respondent with lower education stated:

Actually it should be like that -- I think I am definitely alone [in this focus group] in my opinion -- but somehow you want to be married, want to have a husband, to have the same name, just to identify as a team. (Female, lower education, 25, single, no children)

'Love', commonly believed to be a major motive for marriage, only played a minor role in the group discussions. Marriage was not regarded as a final statement of love. One female respondent in a lower-educated group stated:

Sure, we love each other, we've been together for about 9 or 10 years now, and we just got married last year, and I have to say, we married for economic reasons. Of course, we love each other and all that, but I have to say that we never had a good reason to get married, why should I marry? Everything went well, there were ups and downs, but then we discovered that it wouldn't be that bad, to have some financial advantages. It's sad to say that nowadays you 
marry for that reason and not because you love each other. (Female, lower education)

The following discussion on motives for marrying took place in a group of highereducated men. After respondent MA02 had declared that there are no "objective reasons" for marrying and only minor tax benefits, he went on to say:

MA02: Marriage as a symbol, a frame. That's a reason.

MA01: But initially you said that you didn't need a reason or a symbol for showing your love for one another?

MA02: No, but I imagine that it is a reason for others.

MA10: The question was why we marry at all.

MA01: No one here mentioned real love. That could be a reason, too.

T: But that's not a reason for a wedding.

MA01: I don't know. I don't know either why some marry.

T: Love is free today. You can love the way you want to.

In summary, there are romantic motives for marrying, and some people see marriage as a special sign of love or commitment to their partner, but these motives are not prevalent. Instead, having children is seen as a much stronger sign of togetherness. There are also economic motives such as tax benefits, but they are not very convincing because respondents implicitly acknowledge the fact that both members of a partnership will work full-time and will earn approximately the same amount of money; in which case the German tax system has no advantages for married couples.

\subsection{Relating to the GDR past - the changing role of the state}

The previous sections have listed several factors relevant to getting married and reasons for getting married (or not). What stood out, however, was that almost all the focus groups had a general awareness of a change in the way of life. This was usually mentioned at the very start of the discussion, following the initial question on reasons for the declining marriage rate. In addressing this question, respondents immediately mentioned the end of the GDR and its regulations, and the fact that all of the reasons that made marriage in GDR times a self-evident step to be taken early in life no longer existed. The incentives for early marriage in GDR times were well known. There are no longer comparably strong incentives to choose a specific way of living together: 
Back then there were social enforcements so that you simply had to marry, for economic reasons, too. (...). For example, I'm thinking about the 'marriage loans' for newly wed couples, so they could buy furnishings. There was no other way to get a loan (...). Today I go into a furniture store and buy my whole apartment on loan, just pay in installments. (Male, 40, lower education, single, no children)

Respondents related to their parents' and grandparents' experiences and mentioned the strong motives for marriage back in "GDR times".

...marriage has lost the status it had for our grandparents and parents. ... What marriage meant for our parents does not exist anymore. ... I know that my parents got married because a child was on the way, because that's how they got an apartment. It's not like that anymore. Today I can choose my apartment. In GDR times it wasn't like that, let's not fool ourselves. People with many children got loans, but that was only if you were married. (Female, higher education, divorced)

Respondents in the focus groups often attributed changes in marriage and fertility patterns in eastern Germany to the abolition of policies promoting early childbirth and marriage:

I mean, family is no longer important, if only because of the shortage economy we had back then - that's all over now. It was an economic factor, residence flat, a car and house, everything was all planned, it was dictated by the state, it isn't like that anymore. Today you can get everything, if you have the money for it. (Male, 39, lower education, single, no children)

Analyzing these statements on the situation in the GDR tells us something about the situation today. Respondents said that compared with GDR times there is now little incentive to marry or have children. The most frequent reference was to the housing situation in the GDR (20 times over all groups). Apartments were rare, and preference was given to married couples. This was a very strong incentive for young people to marry, because otherwise they had to live in their parents' apartment.

I grew up in the GDR, so I know this attitude of saying: you get married because you need an apartment. When it comes down to it, I knew very few who said, we're getting married for love, we love each other. [...] but often you heard, we're getting married and then we'll get an apartment sooner, then 
we'll get the marriage loan. So this was for economic reasons [...]. (Female, 39, higher education, partnership, no children)

Other incentives to marry in the GDR named by the participants were subsidiary grants for newly married couples (7 times over all groups) and more extensive governmental childcare (6 times). Although we did not code any other incentives to marry or have children, in general the situation in the GDR was often considered to be more family friendly.

I question if the state still even supports this model of family, marriage. In GDR times it was supported, it was promoted on every level. (Female, 40, higher education, single, with children)

Knowledge about current specific legal conditions concerning marriage and cohabitation is low:

In GDR times a bunch of laws existed. I don't know if today there is anything that promotes marriage in some way. (Male, 37, higher education, partnership, with children)

Again, this statement shows that relating their own situations to those of their parents and grandparents is a very important factor in the formation and evaluation of respondents' own attitudes and intentions regarding marriage and living in a relationship. However, even if some group discussions indicated regret that there are no longer sufficient state incentives for marriage or that state support for couples with children is low, the respondents did not lament this, nor did they wish themselves back in GDR times. They valued the freedoms they have gained but they were well aware of the past. One older respondent phrased it this way:

I'm glad to have had the experience [of GDR-times], but I'm glad it's over. I do not want to have it back.

\section{Summary and discussion}

Our focus group results suggest that current generalized theoretical explanations can only partially explain the declining marriage rate and rising level of non-marital childbearing when applied to specific countries. These theories need to be complemented by country- or region-specific explanations that are sensitive to 
historical and cultural context and consider the influence of social interactions and norms.

There are some limitations to this study. First, the sample is not representative in a strict sense, and the focus groups were held in a city rather than across different regions and in both urban and rural settings in eastern Germany. However, as argued in Section 4.1, Rostock is in many ways very typical of eastern Germany, and the family politics of the GDR many of our respondents refer to were uniform across the whole of eastern Germany until 1990. We stratified our sample by gender and education. The participants lived in various union arrangements (partnership, married, single), with or without children, and differed considerably in age. Our participants had very different living situations and life experiences. Thus, we are confident that our main conclusions hold true for eastern Germany. Second, unlike narrative in-depth interviews, the focus group method does not provide insight into the individual or couple-level process of decision-making concerning marriage or cohabitation. However, focus groups elicit social norms that are commonly shared. The method shows how strong these norms are and how strictly they are sanctioned, thus giving more information about the context in which individual decisions are made.

To summarize our results, the focus groups in eastern Germany show that economic uncertainty is one factor influencing peoples' decisions to engage in longterm commitments such as marriage and childbearing. These findings support the argument that economic uncertainty influences family formation (Mills and Blossfeld 2003, Sobotka and Toulemon 2008, and Perelli-Harris et al. 2010). However, our results, in line with the research of Bernardi, Klärner, and von der Lippe (2008), show that individuals and couples in eastern Germany deal with those social conditions they cannot control or change in a flexible and pragmatic way. Job mobility, short-term contracts, the need to adapt to changing labor markets etc., are often appreciated and interpreted as opportunities. These attitudes are clearly influenced by the collective memory of GDR times, in which jobs and careers were more or less planned by the state, giving individuals only a limited choice of where to work and what to do (Huinink, Mayer, and Trappe 1995). Respondents in the focus groups referred negatively to the planned state careers their parents had to follow, and they value the free choice of career that they have today.

These individualization and modernization processes are influential, and our respondents stressed the new opportunities to plan and chose their own lives individually, in contrast to former GDR times. They overwhelmingly cherished these new opportunities but also argued that these opportunities have served to make marriage one choice among other competing choices. Thus, marriage has become less self-evident than it was two or three decades ago. 
Most importantly - and this is the main contribution this work makes to the theoretical debate on changing family patterns - we find that memories of the past and comparisons of current and historical conditions play a striking role in respondents' reasoning about marriage, cohabitation, and childbearing. The focus groups show that the meaning of marriage has changed, and that it no longer plays the same role in society as it once did. Our focus group results suggest that historical and cultural traditions influence attitudes and decision-making about marriage in several ways.

First, our focus group participants demonstrated a very high acceptance of longterm or permanent cohabitation and did not stigmatize non-marital births. As suggested by Klüsener and Goldstein (2014), these liberal attitudes seem to reflect socio-structural factors and laws that date back as far as the $18^{\text {th }}$ century, when Prussian civil law supported lone mothers. GDR legislation sustained this tradition and our respondents continue to hold liberal attitudes. For them it is important that children have a mother and father or a single mother who care(s) for the children. The legal marital status of the parents is widely believed to be irrelevant to the wellbeing of children. This general cultural climate of acceptance of cohabitation and non-marital childbearing in eastern Germany hints at an absence of the social pressure to get married in the case of pregnancy that has been present in other countries until very recently (Cartwright 2000; Munoz-Pérez and Prioux 2000). In this sense, cohabitation in eastern Germany seems to be an "alternative to marriage" or is even becoming "indistinguishable from marriage" (Heuveline and Timberlake 2004).

Second, in line with research on female employment patterns in the GDR and gender and work in eastern and western Germany before and after unification (Rosenfeld, Trappe, and Gornick 2004; Trappe 1995, 1996; Trappe and Rosenfeld 1998, 2004; Trappe and Sørensen 2006), in the GDR women were integrated into the labor force. Full-time female employment was the norm and mothers returned to work early after childbirth. Female employment rates have diminished, due to economic restructuring and unemployment after unification, but are still much higher than in western Germany. In line with research on the ideals of motherhood and the acceptance of female employment in Europe (Scott 1999; Treas and Widmer 2000; Goldstein and Kreyenfeld 2011) and our earlier research (Bernardi, Klärner, and von der Lippe 2008; Klärner and Keim 2011), our focus groups show that female employment and full-time working mothers are still a cultural norm. Full-time employment of women and mothers is widely accepted and expected, and respondents in our focus groups often referred to their own experience as children of working mothers. This is perceived to be 'normal' and is not thought to pose any harm to the child. By being employed full-time and contributing equally to the household income, women are also more able to provide for themselves, which diminishes the husband's economic function of providing for the child-caring mother. Thus marriage also loses a great deal of its security function. 
As a result of these higher female employment rates, women are more economically independent of the male breadwinner. Women who assume they will be working, regardless of being mothers or not, do not need to rely on their partner's income. In line with earlier research (Bernardi, Klärner, and von der Lippe 2008), the focus group participants expected that both partners in a relationship would work and contribute more or less equally to the household income. This, coupled with the peculiarities of the German tax system, which gives financial benefits to married couples only in situations in which one partner earns considerably more money than the other, means that there are far fewer economic incentives for marriage and that marriage has lost part of its function and has become more or less devoid of meaning (Schneider and Rüger 2007).

Third, the respondents in our focus groups compared their own motives and incentives for marriage with those that existed in GDR times. They know from their parents that there used to be strong incentives for early marriage, but these incentives no longer exist and therefore no longer influence their own decision-making. Instead, they see the incentives for marriage today as being so minor, or as holding so little promise for their own personal situation, that their effect is negligible. Respondents in our focus groups were well aware of the differences between GDR family policies and those in place today; when asked to cite reasons in favor of marriage they often struggled to come up with any at all. This balancing and calculating of the (financial) benefits of marriage is propelled by the secularized tradition established during the socialist, anti-religious system of the GDR. Rational arguments for and against marriage gained ground over religious motivation and favored the rational behavior of individuals. Since unification many of the financial benefits of marriage have simply been abandoned, and there are fewer rational reasons for marriage. To verify that our findings are unique to eastern Germany, future research will compare the results from eastern Germany with focus groups held in Lübeck in western Germany.

To conclude, for the respondents in our focus groups, marriage has lost a great deal of its social and individual meaning, especially compared to its importance for previous generations. Nevertheless, the idea of two persons willing to live together and spend a long time - perhaps even the rest of their lives - together is still valid, but marriage is not needed to document this willingness. When people still choose to marry it has a more individual meaning (Schneider and Rüger 2007) or can be seen as the "capstone" (Holland 2013) of a relationship, but, in contrast to the findings of Schneider and Rüger (2007), marriage is not necessarily seen as a covenant for life. 


\section{Acknowledgements}

This research was funded by Brienna Perelli-Harris's ERC CHILDCOHAB starting grant. I am very grateful to Daniela Georges and André Knabe, who assisted in conducting the FGs and performed the first round of coding of the material. The article benefited from discussions with Focus on Partnership team members during workshops. I am grateful to Brienna Perelli-Harris, Laura Bernardi, and two anonymous reviewers of Demographic Research for their valuable comments. 


\section{References}

Arranz-Becker, O., Lois, D., and Nauck, B. (2010). Differences in fertility patterns between east and west German women: Disentangling the roles of cultural background and of the transformation process. Comparative population studies 35(1): 7-34. doi:10.4232/10.CPoS-2010-02en.

Axinn, W. and Thornton, A. (2000). The transformation in the meaning of marriage. In: Waite, L.J. (ed.). The ties that bind: Perspectives on marriage and cohabitation. New York: Aldine de Gruyter: 147-165.

Barbour, R. (2007). Doing focus groups. Los Angeles: SAGE.

Barlow, A. (2004). Regulation of cohabitation, changing family policies and social attitudes: A discussion of Britain within Europe. Law \& Policy 26(1): 57-86. doi:10.1111/j.0265-8240.2004.00163.x.

Barlow, A. and Probert, R. (2004). Regulating marriage and cohabitation: Changing family values and policies in Europe and North America: An introductory critique. Law \& Policy 26(1): 1-11. doi:10.1111/j.0265-8240.2004.00160.x.

Bastin, S., Kreyenfeld, M., and Schnor, C. (2013). Diversität von Familienformen in Ost- und Westdeutschland. In: Herma, H., Schierbaum, A., and Krüger, D. (eds.). Familie(n) heute. Entwicklungen, Kontroversen, Prognosen. Weinheim: Beltz: 126-145.

Bauman, Z. (2007). Liquid times: Living in an age of uncertainty. Cambridge: Polity.

Beck-Gernsheim, E. (1998). On the way to a post-familial family: From a community of need to elective affinities. Theory, Culture \& Society 15(3): 53-70. doi:10.1177/0263276498015003004.

Beck-Gernsheim, E. (2002). Reinventing the family: In search of new lifestyles. Cambridge: Polity.

Beck-Gernsheim, E. (2012). From rights and obligations to contested rights and obligations: Individualization, globalization, and family law. Theoretical Inquiries in Law 13(1): 1-14. doi:10.1515/1565-3404.1283.

Bengtson, V.L. and Allen, K.R. (1993). The life course perspective applied to families over time. In: Boss, P.G., Doherty, W.J., LaRossa, R., Schumm, W.R., and Steinmetz, S.K. (eds.). Sourcebook of family theories and methods: A contextual approach. New York, NY: Springer: 469-504. doi:10.1007/978-0-387-857640_19. 
Bernardi, L., Klärner, A., and von der Lippe, H. (2008). Job insecurity and the timing of parenthood: A comparison between eastern and western Germany. European Journal of Population 24 (3): 287-313. doi:10.1007/s10680-007-9127-5.

Billari, F.C., Liefbroer, A.C., and Philipov, D. (2006). The postponement of childbearing in Europe: Driving forces and implications. Vienna Yearbook of Population Research 4: 1-17.

Bloor, M., Frankland, J., Thomas, M., and Robson, K. (2001): Focus groups in social research. London: SAGE.

Bowman, C.G. (2010). Unmarried couples, law, and public policy. Oxford: Oxford University Press.

Cartwright, K.D. (2000): Shotgun weddings and the meaning of marriage in Russia. The History of the Family 5(1): 1-22. doi:10.1016/S1081-602X(00)00029-4.

Coleman, J.S. (1986). Social theory, social research, and a theory of action. American Journal of Sociology 91(6): 1309-1335. doi:10.1086/228423.

Elder, G.H. (1985). Life course dynamics. Ithaca, NY: Cornell University Press.

Emirbayer, M. and Mische, A. (1998). What is agency? American Journal of Sociology 103(4): 962-1023. doi:10.1086/231294.

Engelhardt, H., Trappe, H., and Dronkers, J. (2002). Differences in family policy and the intergenerational transmission of divorce: A comparison between the former East and West Germany. Demographic Research 6(11): 295-324. doi:10.4054/ DemRes.2002.6.11.

Esping-Andersen, G. (1990). The three worlds of welfare capitalism. Princeton: Princeton University Press.

Esping-Andersen, G. (1999). Social foundations of postindustrial economies. Oxford: Oxford University Press. doi:10.1093/0198742002.001.0001.

Flick, U. (2009). An introduction to qualitative research: Fourth edition. Los Angeles: SAGE.

Friedman, D., Hechter, M., and Kanazawa, S. (1994). A theory of the value of children. Demography 31(3): 375-401. doi:10.2307/2061749.

Froese, P. and Pfaff, S. (2005). Explaining a religious anomaly: A historical analysis of secularization in Eastern Germany. Journal for the Scientific Study of Religion 44(4): 397-422. doi:10.1111/j.1468-5906.2005.00294.x. 
Gibson-Davis, C.M., Edin, K., and McLanahan, S. (2005). High hopes but even higher expectations: The retreat from marriage among low-income couples. Journal of Marriage and the Family 67(5): 1301-1312. doi:10.1111/j.1741-3737.2005. 00218.x.

Goldstein, J.R. and Kreyenfeld, M. (2011). Has east Germany overtaken west Germany?: Recent trends in order-specific fertility. Population and Development Review 37(3): 453-472. doi:10.1111/j.1728-4457.2011.00430.x.

Graham, H. and McDermott, E. (2006). Qualitative research and the evidence base of policy: Insights from studies of teenage mothers in the UK. Journal of Social Policy 35(1): 21-37. doi:10.1017/S0047279405009360.

Granovetter, M.S. (1985). Economic action and social structure: The problem of embeddedness. American Journal of Sociology 91(3): 481-510. doi:10.1086/ 228311.

Heuveline, P. and Timberlake, J.M. (2004). The role of cohabitation in family formation: The United States in comparative perspective. Journal of Marriage and the Family 66(5): 1214-1230. doi:10.1111/j.0022-2445.2004.00088.x.

Holland, J.A. (2013). Love, marriage, then the baby carriage? Marriage timing and childbearing in Sweden. Demographic Research 29(11): 275-306. doi:10.4054/ DemRes.2013.29.11.

Huinink, J., Kreyenfeld, M., and Trappe, H. (2012). Familie und Partnerschaft in Ostund Westdeutschland. Ähnlich und doch immer noch anders. Opladen: Budrich.

Huinink, J., Mayer, K.U., and Trappe, H. (1995). Staatliche Lenkung und individuelle Karrierechancen. Bildungs- und Berufsverläufe. In: Huinink, J. and Mayer, K.U. (eds.). Kollektiv und Eigensinn. Lebensverläufe in der DDR und danach. Berlin: Akademie Verlag: 89-143. doi:10.1524/9783050071497.89.

Hunink, J. and Wagner, M. (1995). Partnerschaft, Ehe und Familie in der DDR. In: Huinink, J. and Mayer, K.U. (eds.). Kollektiv und Eigensinn. Lebensverläufe in der DDR und danach. Berlin: Akademie Verlag: 145-188. doi:10.1524/97830 50071497.145 .

Inglehart, R. (1977). The silent revolution: Changing values and political styles among western publics. Princeton, NJ: Princeton University Press.

Inglehart, R. (1997). Modernization and postmodernization: Cultural, economic, and political change in 43 societies. Princeton, NJ: Princeton University Press. 
Kalmijn, M. (2007). Explaining cross-national differences in marriage, cohabitation, and divorce in Europe, 1990-2000. Population Studies: A Journal of Demography 61(3): 243-263. doi:10.1080/00324720701571806.

Keller, S. and Marten, C. (2012). Jugend (wieder-)vereinigt? Die Familien- und Berufserwartungen ost- und westdeutscher Jugendlicher. In: Huinink, J., Kreyenfeld, M., and Trappe, H. (eds.). Familie und Partnerschaft in Ost- und Westdeutschland. Ähnlich und doch immer noch anders. Opladen: Budrich: 299318.

Klärner, A. and Keim, S. (2011). (Re-)Traditionalisierung und Flexibilität. Intergenerationale Unterstützungsleistungen und die Reproduktion von Geschlechterungleichheiten in West- und Ostdeutschland. In: Berger, P.A., Hank, K., and Tölke, A. (eds.). Reproduktion von Ungleichheit durch Arbeit und Familie. Wiesbaden: VS: 121-144. doi:10.1007/978-3-531-94117-2_6.

Klenner, C. (2009). Wer ernährt die Familie? Erwerbs- und Einkommenskonstellationen in Ostdeutschland. WSI-Mitteilungen (11): 619-626.

Klüsener, S. and Goldstein, J.R. (2014). A Long-Standing Demographic East-West Divide in Germany. Population, Space and Place (Online First). doi:10.1002/ psp.1870.

Klüsener, S. and Kreyenfeld, M. (2009). Nichteheliche Geburten im regionalen Vergleich [electronic resource]. Leipzig: Leibniz-Institut für Länderkunde. http://aktuell.nationalatlas.de/Nichteheliche_Geburten.10_10-2009.0.html.

Klüsener, S., Perelli-Harris, B., and Sánchez Gassen, N. (2013). Spatial aspects of the rise of nonmarital fertility across Europe since 1960: The role of states and regions in shaping patterns of change. European Journal of Population 29(2): 137-165. doi:10.1007/s10680-012-9278-x.

Konietzka, D. and Kreyenfeld, M. (2002). Women's employment and non-marital childbearing: A comparison between East and West Germany in the 1990s. Population (English Edition) 57(2): 331-357. doi:10.3917/popu.202.0359.

Krause, P. and Ostner, I. (2010). Leben in Ost- und Westdeutschland. Eine sozialwissenschaftliche Bilanz der deutschen Einheit 1990 - 2010. Frankfurt am Main: Campus.

Kravdal, O. (1999). Does marriage require a stronger economic underpinning than informal cohabitation? Population Studies 53(1): 63-80. doi: 10.1080/003247 20308067. 
Kreyenfeld, M. and Konietzka, D. (2008). Wandel der Geburten und Familienentwicklung in West- und Ostdeutschland. In: Schneider, N.F. (ed.). Lehrbuch Moderne Familiensoziologie: Theorien, Methoden, empirische Befunde. Opladen and Farmington Hills: Barbara Budrich: 123-137.

Kreyenfeld, M. and Konietzka, D. (2010). Nichteheliche Geburten. In: Max-PlanckInstitut für demografische Forschung (ed.). Familie und Partnerschaft in Ostund Westdeutschland. Rostock: MPIDR: 8-9.

Lesthaeghe, R. (2010). The unfolding story of the Second Demographic Transition. Population and Development Review 36(2): 211-251. doi:10.1111/j.17284457.2010.00328.x.

Levin, I. (2004). Living apart together: A new family form. Current Sociology 52(2): 223-240. doi:10.1177/0011392104041809.

Liamputtong, P. (2011): Focus group methodology: Principles and Practice. London: SAGE.

Manting, D. (1996). The changing meaning of cohabitation and marriage. European Sociological Review 12(1): 53-65. doi:10.1093/oxfordjournals.esr.a018177.

Mayer, K.U. (2009). New Directions in Life Course Research. Annual Review of Sociology 35: 413-433. doi:10.1146/annurev.soc.34.040507.134619.

Mayer, K.U. and Schulze, E. (2009). Die Wendegeneration. Lebensverläufe des Jahrgangs 1971. Frankfurt am Main: Campus.

Mayer, K.U. and Solga, H. (2010). Lebensverläufe im deutsch-deutschen Vereinigungsprozess. In: Krause, P. and Ostner, I. (eds.). Leben in Ost- und Westdeutschland. Eine sozialwissenschaftliche Bilanz der deutschen Einheit 1990 - 2010. Frankfurt am Main: Campus: 39-56.

McDonald, P. (2006). Low fertility and the state: The efficacy of policy. Population and Development Review 32(3): 485-510. doi:10.1111/j.1728-4457.2006. 00134.x.

Meulemann, H. (2003). Erzwungene Säkularisierung in der DDR - Wiederaufleben des Glaubens in Ostdeutschland? Religiöser Glaube in ost- und westdeutschen Alterskohorten zwischen 1991 und 1998. In: Gärtner, C., Pollack, D., and Wohlrab-Sahr, M. (eds.). Atheismus und religiöse Indifferenz. Opladen: Leske + Budrich: 247-270. 
Mills, M. and Blossfeld, H.-P. (2003). Globalization, uncertainty and changes in early life courses. Zeitschrift für Erziehungswissenschaft 6(2): 188-218. doi:10.1007/ s11618-003-0023-4.

Munoz-Pérez, F. and Prioux, F. (2000). Children born outside marriage in France and their parents: Recognitions and legitimations since 1965. Population 12(1): 139195.

Mynarska, M. and Bernardi, L. (2007). Meanings and attitudes attached to cohabitation in Poland: Qualitative analyses of the slow diffusion of cohabitation among the young generation. Demographic Research 16(17): 519-554.

Nazio, T. and Blossfeld, H.-P. (2003). The diffusion of cohabitation among young women in West Germany, East Germany and Italy. European Journal of Population 19(1): 47-82. doi:10.1023/A:1022192608963.

Oppenheimer, V.K. (2003). Cohabiting and marriage during young men's career-development process. Demography 40(1): 127-149. doi:10.1353/dem.2003.0006.

Oppenheimer, V.K., Kalmijn, M., and Lim, N. (1997). Men’s career development and marriage timing during a period of rising inequality. Demography 34(3): 311330. doi:10.2307/3038286.

Patton, M. Q. (2002). Qualitative research and evaluation methods. London: SAGE.

Perelli-Harris, B. and Sánchez Gassen, N. (2012). How similar are cohabitation and marriage?: Legal approaches to cohabitation across western Europe. Population and Development Review 38 (3): 435-467. doi:10.1111/j.1728-4457.2012. 00511.x.

Perelli-Harris, B., Kreyenfeld, M., Sigle-Rushton, W., Keizer, R., Lappegård, T., Jasilioniene, A., Berghammer, C., and Di Giulio, P. (2012). Changes in union status during the transition to parenthood in eleven European countries, 1970s to early 2000s. Population Studies 66(2): 167-182. doi:10.1080/00324728. 2012.673004.

Perelli-Harris, B., Mynarska, M., Berrington, A., Evans, A., Berghammer, C., Isupova, O., Keizer, R., Klärner, A., Lappegård, T., and Vignoli, D. (2014). Towards a new understanding of cohabitation: Insights from focus group research across Europe and Australia. Demographic Research 31(34): 1043-1078. doi:10.4054/ DemRes.2014.31.34. 
Perelli-Harris, B., Sigle-Rushton, W., Kreyenfeld, M., Lappegård, T., Keizer, R., and Berghammer, C. (2010). The educational gradient of childbearing within cohabitation in Europe. Population and Development Review 36(4): 775-801. doi:10.1111/j.1728-4457.2010.00357.x.

Peuckert, R. (2012). Familienformen im sozialen Wandel. Wiesbaden: VS.

Pfau-Effinger, B. and Geissler, B. (2002). Cultural change and family policies in East and West Germany. In: Carling, A., Duncan, S. and Edwards, R. (eds.). Analysing families: Morality and rationality in policy and practice. London: Routledge: 77-83.

Pfau-Effinger, B. and Smidt, M. (2011). Differences in women's employment patterns and family policies: eastern and western Germany. Community, Work \& Family 14(2): 217-232. doi:10.1080/13668803.2011.571401.

Pickel, G. (2012). Religiosity and bonding to the church in East Germany in eastern European Comparison: Is East Germany still following a special path? In: Pickel, G. and Sammet, K. (eds.). Transformations of religiosity. Wiesbaden: VS: 135-154. doi:10.1007/978-3-531-93326-9.

Ramsøy, N.R. (1994). Non-marital cohabitation and change in norms: The case of Norway. Acta Sociologica 37(1): 23-37. doi:10.1177/000169939403700102.

Rosenfeld, R.A., Trappe, H., and Gornick, J.C. (2004). Gender and work in Germany: Before and after reunification. Annual Review of Sociology 30: 103-124. doi:10.1146/annurev.soc.30.012703.110531.

Salles, A. (2006). The effects of family policy in the former GDR on nuptiality and births outside marriage. Population (English Edition) 61(1/2): 141-151. doi:10.3917/popu.601.0141.

Schneider, N.F. and Rüger, H. (2007). Value of Marriage: Der subjektive Sinn der Ehe und die Entscheidung zur Heirat. Zeitschrift für Soziologie 36(2): 131-152.

Schnor, C. (2012). Trennungsrisiko von Paaren mit Kindern: Der Einfluss der Religion in West-und Ostdeutschland. Journal of Family Research, Special Issue (9): 229-256.

Scott, J. (1999). European attitudes towards maternal employment. International Journal of Sociology and Social Policy 19: 144-177. doi:10.1108/014433 39910788929. 
Sobotka, T. and Toulemon, L. (2008). Overview chapter 4: Changing family and partnership behaviour. Demographic Research 19: 85-138. doi:10.4054/Dem Res.2008.19.6.

Sobotka, T., Skirbekk, V., and Philipov, D. (2011). Economic recession and fertility in the developed world. Population and Development Review 37(2): 267-306. doi:10.1111/j.1728-4457.2011.00411.x.

Statistische Ämter des Bundes und der Länder (2014). Zensus 2011 - Bevölkerung nach Geschlecht, Alter, Staatsangehörigkeit, Familienstand und Religionszugehörigkeit [electronic resource]. http://www.statistikportal.de/ statistik-portal/Zensus_2011_Bevoelkerung.pdf.

Statistisches Amt Mecklenburg-Vorpommern (2011). Zensus 2011. Bevölkerung und Haushalte. Kreisfreie Stadt Rostock [electronic resource]. http://rathaus.rostock. de/sixcms/media.php/1493/Hansestadt\%20Rostock_Zensus\%202011_BEV\%C3 \%96LKERUNG_endg\%C3\%BCltig.pdf [11.2.2015].

Stewart, D.W., Shamdasani, P.N., and Rook, D.W. (2007). Focus groups: Theory and practice. Thousand Oaks: SAGE.

Surkyn, J. and Lesthaeghe, R. (2004). Value orientations and the second demographic transition (SDT) in northern, western and southern Europe: An update. Demographic Research, Special Collection 3: 45-75. doi:10.4054/DemRes. 2004.S3.3.

Thornton, A., Axinn, W.G., and Xie, Y. (2007). Marriage and cohabitation. Chicago: The University of Chicago Press. doi:10.7208/chicago/9780226798684. 001.0001 .

Thornton, A. and Philipov, D. (2009). Sweeping changes in marriage, cohabitation and childbearing in central and eastern Europe: New insights from the developmental idealism framework. European Journal of Population 25(2): 123-156. doi:10.1007/s10680-009-9181-2.

Träger, J. (2009). Familie im Umbruch: Quantitative und qualitative Befunde zur Wahl von Familienmodellen. Wiesbaden: VS.

Trappe, H. (1995). Emanzipation oder Zwang?: Frauen in der DDR zwischen Beruf, Familie und Sozialpolitik. Berlin: Akademie Verlag. doi:10.1515/9783050 071510. 
Trappe, H. (1996) Work and family in women's lives in the German Democratic Republic. Work and Occupations 23(4): 354-377. doi:10.1177/073088849 6023004003.

Trappe, H. and Rosenfeld, R.A. (1998). A comparison of job-shifting patterns in the former East Germany and the former West Germany. European Sociological Review 14(4): 343-368. doi:10.1093/oxfordjournals.esr.a018244.

Trappe, H. and Rosenfeld, R.A. (2004). Occupational sex segregation and family formation in the former East and West Germany. Work and Occupations 31(2): 155-192. doi:10.1177/0730888404263895.

Trappe, H. and Sørensen, A. (2006). Economic relations between women and their partners: An east and west German comparison after reunification. Feminist Economics 12(4): 643-665. doi:10.1080/13545700600885255.

Treas, J. and Widmer, E.D. (2000). Married women's employment over the life course: Attitudes in cross-national perspective. Social Forces 78(4): 1409-1436. doi:10.1093/sf/78.4.1409.

van de Kaa, D.J. (1987). Europe’s second demographic transition. Population Bulletin of the United Nations 42(1): 1-59.

van de Kaa, D.J. (2001). Postmodern fertility preferences: From changing value orientation to new behavior. Population and Development Review 27 (Supplement: Global Fertility Transition): 290-331.

Witte, J.C. and Wagner, G.G. (1995). Declining fertility in East Germany after unification: A demographic response to socioeconomic change. Population and Development Review 21(2): 387-397. doi:10.2307/2137500.

Wohlrab-Sahr, M., Karstein, U., and Schmidt-Lux, T. (2009). Forcierte Säkularität. Religiöser Wandel und Generationendynamik im Osten Deutschlands. Frankfurt am Main, New York: Campus. 